\title{
WEICHSELIAN GLACIAL STRATIGRAPHY IN HYVINKÄÄ, SOUTHERN FINLAND
}

\author{
JOAKIM DONNER
}

\begin{abstract}
DONNER, JOAKIM 1999. Weichselian glacial stratigraphy in Hyvinkää, southern Finland. Bulletin of the Geological Society of Finland 71, Part 2, 223-231.

Two tills in Hyvinkää represent one Weichselian glaciation: the lower till, named the Tanssikallio Till, being a basal lodgement till formed during the initial stage of the last Weichselian glaciation, and the upper till, named the Hyvinkää Till, being a basal melt-out till from the time of the deglaciation of southern Finland, before the formation of the first Salpausselkä marginal terrace. The tills can be compared with those earlier described from Kela west of Helsinki and from Vuosaari in Helsinki. The age of the lower basal lodgement till, when compared with the stratigraphy in Ostrobothnia, is not older than early Middle Weichselian. The possible ice-free interval between the deposition of the two tills at Vuosaari may correspond to the Middle Weichselian interstadial in Estonia. Elsewhere in southern Finland there is no conclusive stratigraphical evidence of an ice-free interval between an early Middle Weichselian and a Late Weichselian ice advance.
\end{abstract}

Key words: glacial features, till, grain size, stratigraphy, Pleistocene, Weichselian, Hyvinkää, Finland

Joakim Donner: Department of Geology, P.O. Box 11, FIN-00014 University of Helsinki, Finland

\section{INTRODUCTION}

The glacial sediments in southern Finland, south of the first Salpausselkä endmoraine, Ss I, which cover the Precambrian bedrock between its numerous outcrops, consist of a rather uniform till bed, and of glacial varved clays as well as of sands and gravels of eskers and endmoraines deposited at the time of the Weichselian deglaciation. The glacial sediments are partly overlain by Holocene clays and beach sands and gravels from the time of the emergence of the coastal area as a result of its uplift; the entire area was submerged during the withdrawal of the ice margin to Ss I.
The till commonly exposed is a sandy till deposited during an ice movement from the northwest, as shown by orientation measurements of its clasts. It has been defined as a basal till (Hirvas et al. 1995) or a basal melt-out till (Bouchard et al. 1990) related to the final retreat of the ice. An older compact dark grey till with higher percentages of clay and silt, deposited during an ice movement from the north, has, in addition, been found at a number of sites, described as the "dark till" (Rainio \& Lahermo 1976, 1984) or the "old till" (Hirvas \& Nenonen 1987). It is correlated with the Siuntio Till west of Helsinki, a lodgement till with striated clasts (Bouchard et al. 1990). The 
Siuntio Till is separated from the overlying sandy melt-out till, the Espoo Till, by sands (Pikkala Sands) interpreted as formed subglacially. Thus both tills were considered to represent the last Weichselian glaciation, the lower Siuntio Till representing the initial stage of the glaciation (Bouchard et al. 1990). At another site, Vuosaari in Helsinki, the only site with three till units, the two upper ones correspond to the two tills described from elsewhere in southern Finland, but they are separated by a glaciolacustrine rhythmite bed, interpreted as having been deposited outside the ice margin, thus representing an ice-free period between two separate ice-flow phases (Hirvas et al. 1995). The interpretation thus differs from that of the sequence west of Helsinki (Bouchard et al. 1990), but at both sites the tills were placed in the Weichselian. The comparatively high percentage of clay, $10-15 \%$, in the dark lodgement till, was taken to show that it contains reworked Eemian marine sediments (Bouchard et al. 1990, Hirvas et al. 1995), but in Sweden similar dark tills occur in areas where no Eemian sediments could have been incorporated (Björnbom 1979, Lundqvist 1986).

At Vuosaari in Helsinki there is lowermost a third till, a cobble-rich sandy basal till, covered by glaciolacustrine laminated silt, clay and fine sand. Underneath the till is a unit of sand with cobbles and boulders, as well as gravel. A preWeichselian, Saalian age for the lowermost till, and the sediments it covers, was mentioned as a possibility in the interpretation of the Vuosaari site (Hirvas et al. 1995). No organic sediments have, however, been found between or below the tills in southern Finland south of Ss I, nor any marine or fresh-water sediments, on the basis of which the tills and related sediments could be placed in the general glacial stratigraphical sequence with any certainty.

The lower till of the two tills described as Weichselian from the above-mentioned sites has also been found preserved underneath the about $2 \mathrm{~km}$ broad esker delta of Kapilamminnummi east of Hyvinkää, exposed at the bottom of a large gravel pit as a $2-4 \mathrm{~m}$ thick bed on top of the underlying bedrock, after removal of 15-20 m of glaciofluvial sand (Kurkinen et al. 1989). The composition and stratigraphical position of the till was compared with the previous finds of similar tills in southern Finland and the relatively high amount of fines was also here interpreted as possibly having been caused by the incorporation of marine Eemian sediments into the till. The Kapilamminnummi site at Hyvinkää is important, as it shows that the till was formed before the deglaciation of the area and before the formation of the esker overlying it.

In 1996 a new section was exposed in Hyvinkää of a brown sandy surface till directly overlying a darker till. The stratigraphy of the earlier recorded site at Kapilamminnummi and of the new section can be compared with the formations of the Weichselian deglaciation, consisting of the first Salpausselkä endmoraine and eskers in front of it, as well as of ridges of De Geer moraines. The present account deals with the glacial stratigraphy in Hyvinkää and its bearing on the stratigraphical sequence in other parts of southern Finland.

\section{STRATIGRAPHY IN HYVINKÄÄ}

A $2.6 \mathrm{~m}$ deep section of two tills was exposed in 1996 in the outskirts of Hyvinkää (Fig. 1), in the northwestern slope of the partly till-covered hill Tanssikallio $60^{\circ} 38^{\prime} 15^{\prime \prime} \mathrm{N}, 24^{\circ} 53^{\prime} 53^{\prime \prime} \mathrm{E}$ (map sheet 204402: $\mathrm{x}=6725.64, \mathrm{y}=2549.12$ ). The tills were exposed for a couple of days in an excavation for the foundations of a garage north of the street of Piilukirveentie in the newly developed Tanssikallio housing area (Fig. 2), just outside the southeastern distal margin of Ss I. The upper till, here termed the Hyvinkää Till, 1.3 m thick below the surface at $126 \mathrm{~m}$ a.s.1., has in the section a sharp contact to the underlying till, here termed the Tanssikallio Till, of which $1.3 \mathrm{~m}$ was exposed. But over a metre was in addition exposed in a ditch dug next to the section and the total thickness of the lower till is thus at least about $2.5 \mathrm{~m}$. The two diamicton units are schematically shown in Fig. 3.

The Tanssikallio Till consists of a compact dark grey silty till with some striated clasts (Fig. 4), and 
with some indication of horizontal stratification. It is interpreted as a basal lodgement till deposited during the last glaciation when the ice advanced over southern Finland. The Hyvinkää Till, on the other hand, is a sandy brown till with angular clasts, a till considered to represent a basal meltout till related to the final deglaciation, in agreement with the above-mentioned conclusions of tills elsewhere in southern Finland (cf. Bouchard et al. 1990). The two tills in the Tanssikallio section at Hyvinkää thus represent two facies of tills deposited during one single glaciation, here without any sediments separating them.

The grain-size curves in Fig. 5 show the difference between the two tills, the Tanssikallio Till having clearly more fines than the Hyvinkää Till. The earlier mentioned till preserved underneath the esker delta at Kapilamminnummi east of Hyvinkää (Kurkinen et al. 1989) has, as seen in Fig. 5, a composition similar to the Tanssikallio Till with which it can be correlated (Fig. 3). The composition of these two tills differs not only from that of the Hyvinkää Till in the Tanssikallio section, but also from the composition of the tills generally analysed from the Hyvinkää area (Tynni 1969) which can be correlated with the Hyvinkää Till.

The section at Kapilamminnummi shows that the dark till, correlated with the Tanssikallio Till, predates the formation of the esker formed during deglaciation. A till with a composition similar to that of the Hyvinkää Till at Tanssikallio, on the other hand, is common at the surface in the Hyvinkää area and is also found in sections of De Geer moraines (Fig. 6) outside the Salpausselkä moraine, showing that the material in the ridges of the De Geer moraines is related to the last till sheet of the area (Fig. 3). The De Geer moraines were formed at the time of deglaciation subglacially in basal crevasses, into which the till was squeezed, in the outer marginal zone of the retreating ice margin (Zilliacus 1987), but their orientation reflects the general direction of the retreating ice margin, as seen from the detailed studies of these moraines in the Hyvinkää area (Aartolahti 1972, Zilliacus 1987). The directions of the De Geer moraines are at an angle to the Salpausselkä

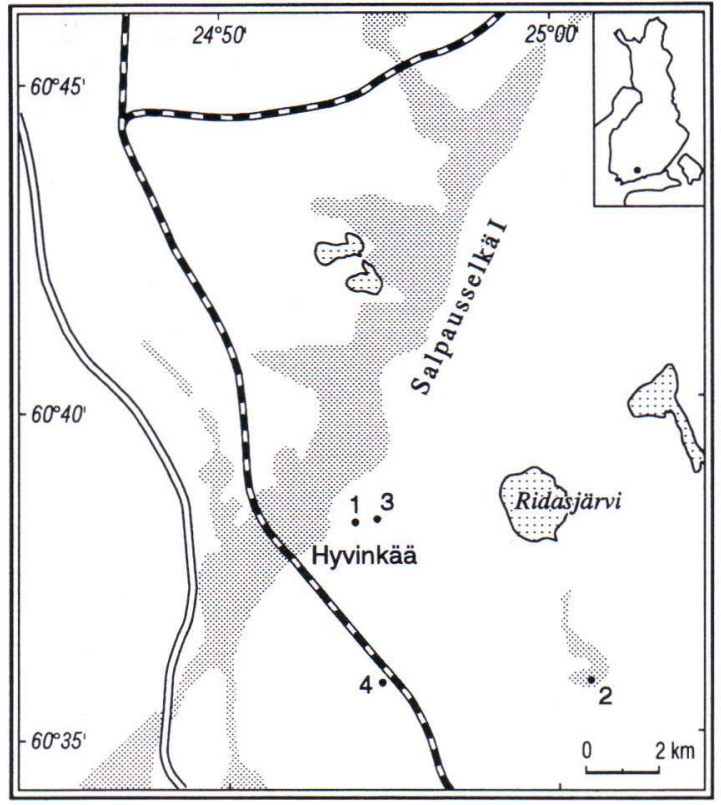

Fig. 1. Sites in Hyvinkää and their relationship to Salpausselkä I and eskers. 1, Tanssikallio; 2, Kapilamminnummi; 3, De Geer moraine at Tiikerinkallio; 4, De Geer moraine at Ilkkala north of Palopuro.

marginal terrace, which indicates that the formation of the marginal formation at Hyvinkää was preceeded by a readvance of the ice margin (Aartolahti 1972). There is no till sheet that can be linked to the readvance, apart from some small local occurrences of a till pushed up by the oscillating ice margin against Salpausselkä and deposited in or on top of the glaciofluvial sediments, particularly in the proximal parts of the marginal terrace (Tynni 1969). This till has been stratigraphically linked with a separate till unit northwest of Ss I formed during the readvance of the ice up to the marginal terrace and therefore called the "Salpausselkä readvance till" (Nenonen 1992). This till is, however, outside the area of Hyvinkää dealt with here.

On the basis of the sites and formations mentioned above, the local glacial lithostratigraphy in Hyvinkää is summarised in Fig. 3. All glacial sediments presumably represent the last Weichselian glaciation of the area. There is no evidence in Hyvinkää of an ice-free interval during this gla- 

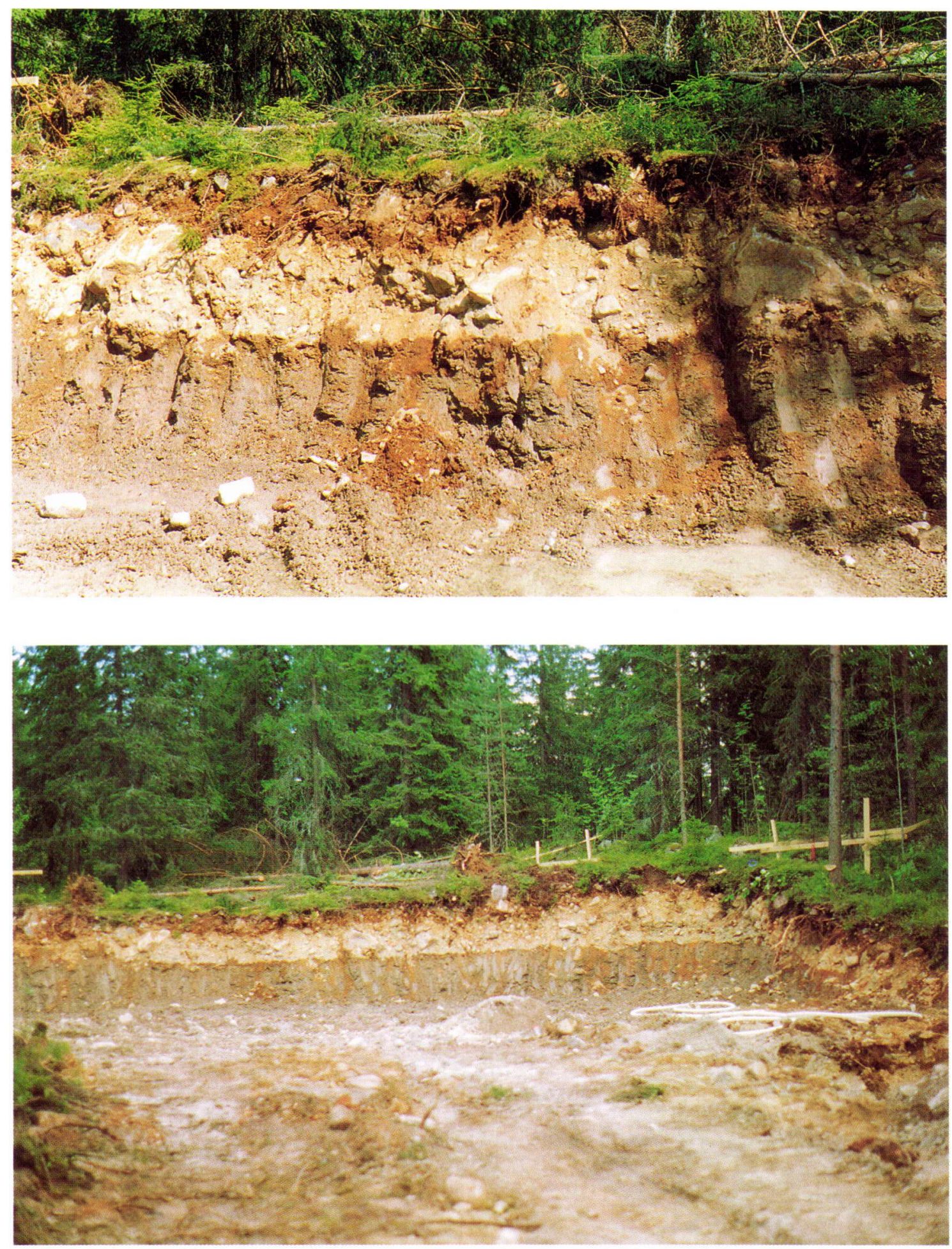

Fig. 2. Two tills at Tanssikallio in Hyvinkää. 


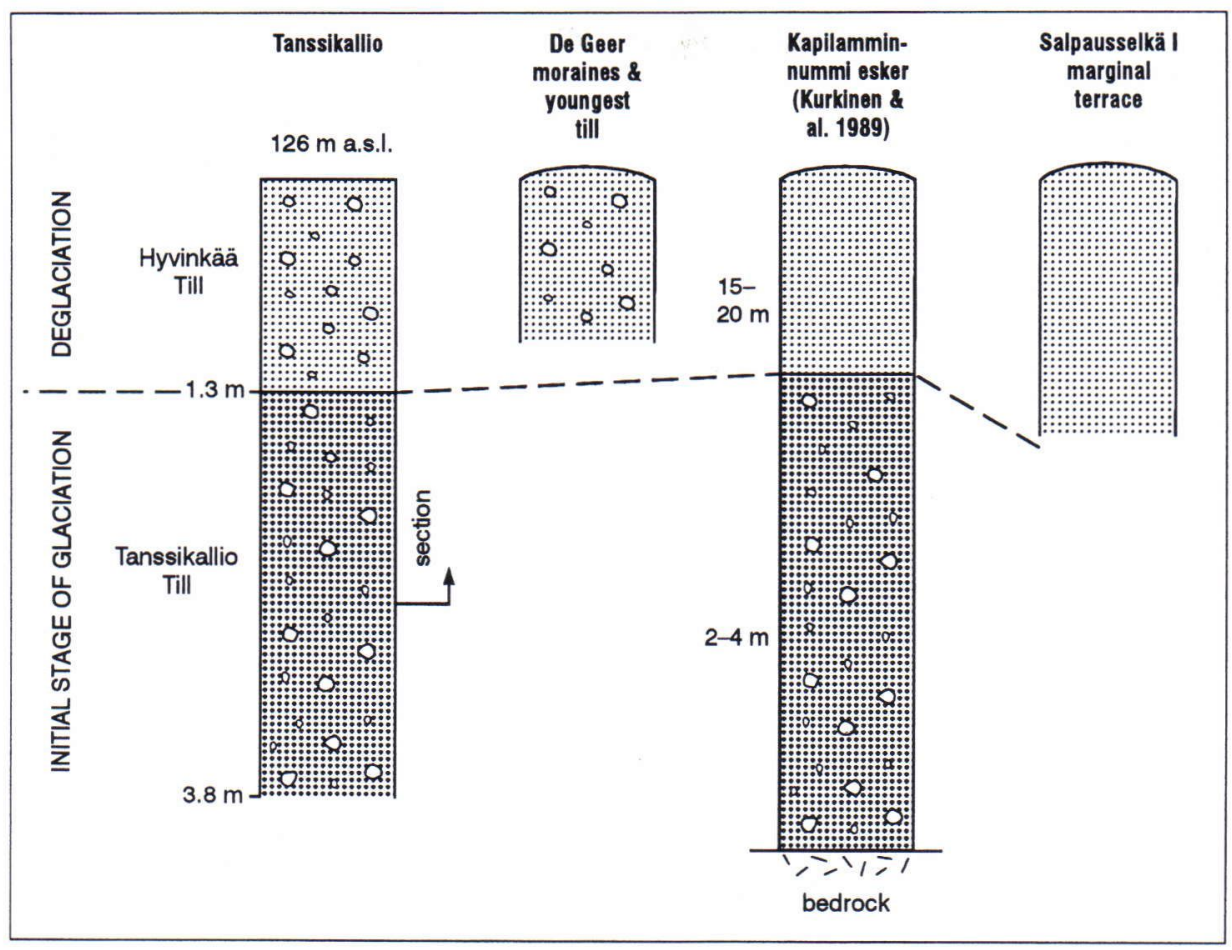

Fig. 3. Glacial stratigraphy in Hyvinkää.

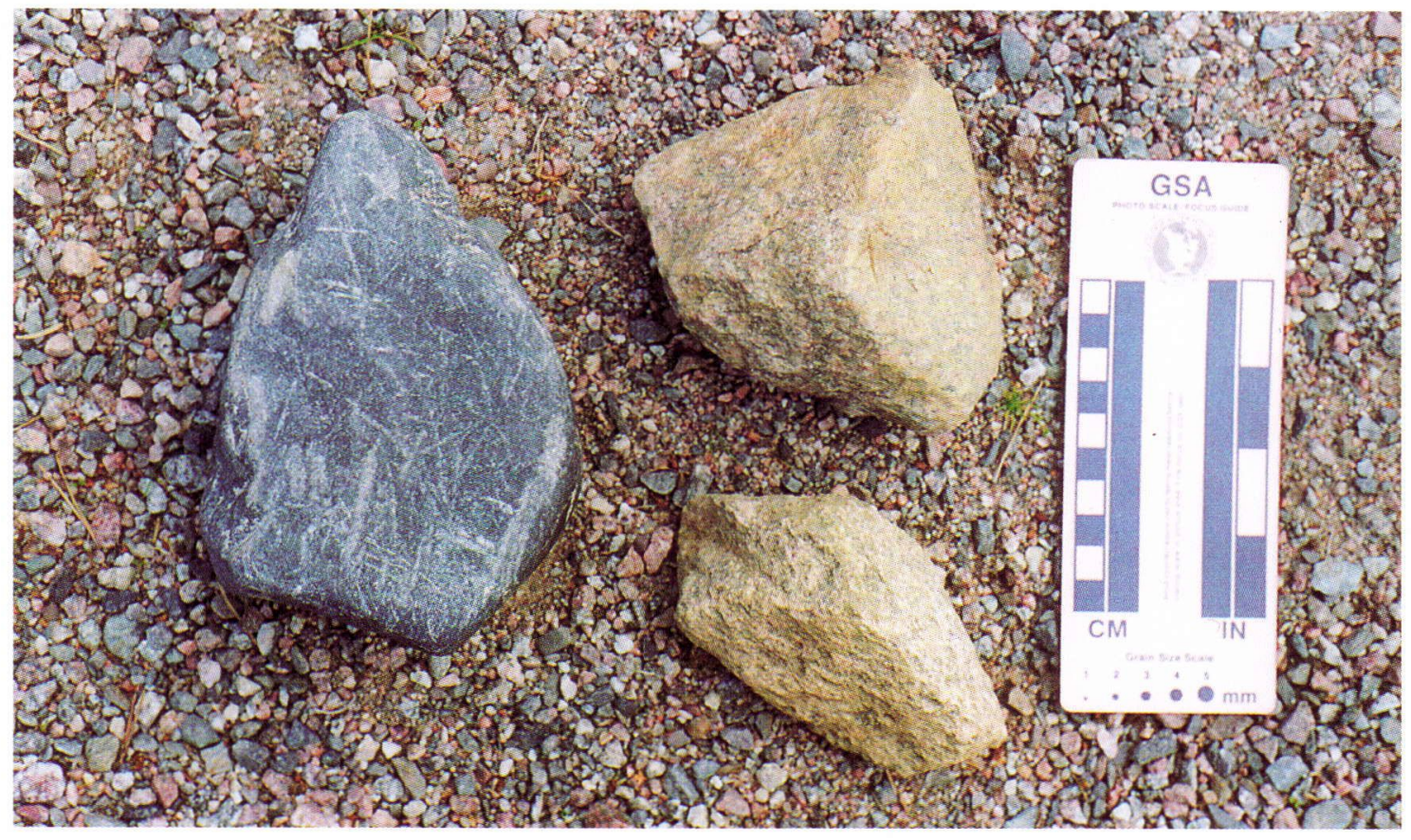

Fig. 4. Left, striated clast of the Tanssikallio Till; right, angular clasts of the Hyvinkäa Till. 


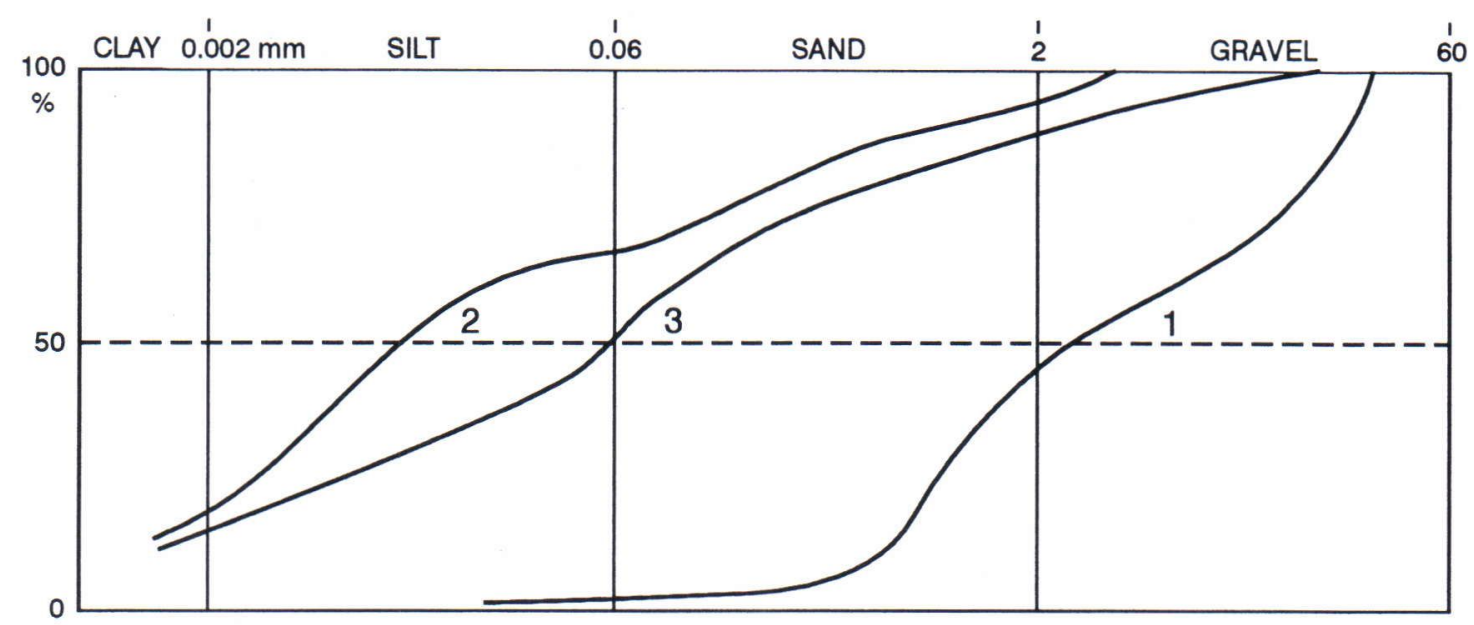

Fig. 5. Grain-size curves for till at Tanssikallio section for Hyvinkää Till (1), Tanssikallio Till (2) and for till below esker delta at Kapilamminnummi (3, from Kurkinen et al. 1989).

ciation. The dark grey basal lodgement till, the Tanssikallio Till, was laid down during the initial stage of the glaciation, whereas the sandy basal meltout till, the Hyvinkää Till, was deposited during the Late Weichselian deglaciation, during which the De Geer moraines were formed subglacially of this till. During the final retreat of the ice margin eskers were deposited, normally on the underlying bedrock; only at one site, at Kapilamminnummi, has the dark basal lodgement till been observed to have been preserved. The retreat of the ice margin was interrupted by the readvance preceding the formation of the marginal terrace of Salpausselkä at Hyvinkää at the end of the Late Weichselian. The retreat of the ice margin took place when the area was submerged under the Baltic Ice Lake.

\section{COMPARISON WITH OTHER AREAS AND GENERAL CONCLUSIONS}

The scheme that can be constructed of the glacial stratigraphy in Hyvinkää and its correlation with that in other parts of southern Finland south of the first Salpausselkä is presented in Table 1. It was concluded that the last glaciation is represented by two tills of which the older is the basal lodgement till, Unit 4 at Vuosaari, Siuntio Till at Kela at the south coast and Tanssikallio Till at Hyvinkää. This is covered by the basal melt-out till, represented by Unit 6 , Espoo Till and Hyvinkää Till respectively. At Kela there are subglacially formed sands between the two tills, as also reported from other sites in southern Finland (Rainio \& Lahermo 1976, Nenonen 1992). At Vuosaari, however, the rhythmite of Unit 5 between the two tills was interpreted as a glaciolacustrine sediment formed during an ice-free interval.

In southern Ostrobothnia a compact dark basal lodgement till, the Kauhajoki Till of Harrinkangas (Gibbard et al. 1989, Bouchard et al. 1990) and tills correlated with it, cover organic sediments of the Oulainen Interstadial and the Evijärvi Interglacial (Table 1). These have been correlated with the Early Weichselian Brørup Interstadial and the Eemian Interglacial, respectively (Donner et al. 1986). The Kauhajoki Till is the only till in southern Ostrobothnia, but it merges in places into a basal melt-out till. Because of the age of the underlying sediments the lodgement till can not be older than Middle Weichselian. If this lodgement till is correlated with the basal lodgement till in southern Finland (Bouchard et al. 1990), the maximum age of the latter is also Middle Weichselian. The fines of this till may be 

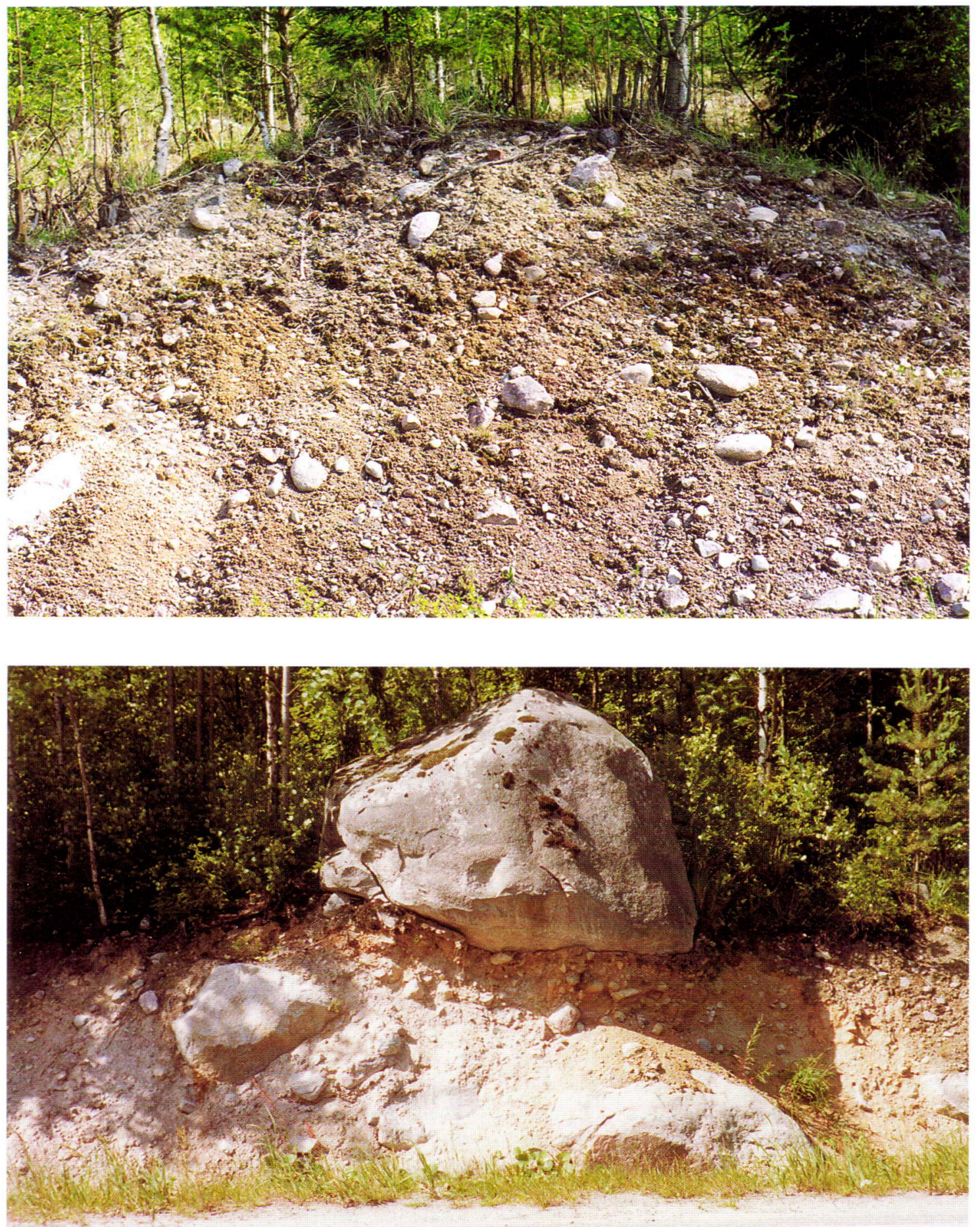

Fig. 6. Above, section of Hyvinkää Till in De Geer moraine at Tiikerinkallio in Hyvinkää and, below, in De Geer moraine at Ilkkala, north of Palopuro (for sites see Fig. 1). 
Table 1. Glacial stratigraphy in southern Finland and southern Ostrobothnia.

\begin{tabular}{|c|c|c|c|c|c|c|}
\hline & & & $\begin{array}{l}\text { Vuosaari, } \\
\text { Helsinki } \\
\text { (Hirvas } \\
\text { et al., 1995) }\end{array}$ & $\begin{array}{l}\text { Kela, W. of } \\
\text { Helsinki } \\
\text { (Bouchard } \\
\text { et al. , 1990) }\end{array}$ & $\begin{array}{l}\text { Hyvinkää } \\
\text { Tanssikallio }\end{array}$ & $\begin{array}{l}\text { Harrinkangas } \\
\text { S. Ostrobothnia } \\
\text { (Gibbard et al., 1989; } \\
\text { Bouchard et al., 1990) }\end{array}$ \\
\hline \multirow{4}{*}{ 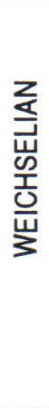 } & Late W. & $\begin{array}{l}\text { Basal melt- } \\
\text { out till }\end{array}$ & Till, Unit 6 & Espoo Till & Hyvinkää Till & \\
\hline & & & $\begin{array}{l}\text { Rhythmite, } \\
\text { Unit } 5 \\
\text { (Glaciolacustrine, } \\
\text { ice free?) }\end{array}$ & $\begin{array}{l}\text { Pikkala Sand } \\
\text { (subglacial) }\end{array}$ & & \\
\hline & Middle W. & $\begin{array}{l}\text { Basal lodge- } \\
\text { ment till }\end{array}$ & Till, Unit 4 & Siuntio Till & Tanssikallio Till & Kauhajoki Till \\
\hline & Early W. & & & & & Oulainen Ist. * \\
\hline \multicolumn{3}{|c|}{ EEMIAN } & & & & Evijärvi lgl. * \\
\hline$\frac{\sum}{\frac{1}{2}}$ & & & $\begin{array}{l}\text { Rhythmite, } \\
\text { Unit } 3 \\
\text { Till, Unit } 2\end{array}$ & & & $\begin{array}{l}\text { "Organic sediments } \\
\text { (Donner et al., 1986) }\end{array}$ \\
\hline
\end{tabular}

redeposited from Eemian marine sediments, as concluded in the earlier mentioned studies and also already in the description of the dark till at Kapilamminnummi east of Hyvinkää (Kurkinen et al. 1989).

According to the reconstruction by Andersen and Mangerud (1990), southern Finland and Ostrobothnia were glaciated from the beginning of the Middle Weichselian to the end of the Late Weichselian. The two tills would thus represent this time. Further, the possible ice-free interval in the sequence at Vuosaari in Helsinki (Hirvas et al. 1995) would most likely be between the early Middle Weichselian ice advance and the more extensive Late Weichselian advance, as separated in the schematic glaciation curves for Scandinavia (Andersen \& Mangerud 1990, Donner 1995). A possible Middle Weichselian ice-free interval in southernmost Finland would be in agreement with the two-fold Weichselian glaciation suggested by Liivrand (1991) for Estonia, with an early Middle Weichselian ice advance and a Late Weichselian ice advance, interrupted by an interstadial, the ice advances having deposited separate tills (see also Raukas \& Kajak 1997). The extent of the ice-free area in Scandinavia at the time between the early Middle Weichselian and Late Weichselian glacial advances is still not known and can not be determined by using till stratigraphy alone.

Several radiocarbon ages of mammoth bones, teeth or tusks in glacial deposits indicate that southern and central Finland was ice-free during the Middle Weichselian (Ukkonen et al. 1999). The finds cannot, however, be related to the till stratigraphy as described above. An alternative explanation to that given in Table 1 is that the icefree Middle Weichselian interval preceded the deposition of both Weichselian tills, but then the possible ice-free interval in southern Finland between the two tills is difficult to explain.

ACKNOWLEDGEMENTS. The author is grateful to Juha Pekka Lunkka for providing the grain-size curves for the two tills in Hyvinkää and to Tuija Jantunen for drawing the figures. 


\section{REFERENCES}

Aartolahti, T. 1972. On deglaciation in southern and western Finland. Fennia 114. 84 p.

Andersen, B.G. \& Mangerud, J. 1990. The last interglacial-glacial cycle in Fennoscandia. Quaternary International 3/4, 21-29.

Björnbom, S. 1979. Clayey basal till in central and northern Sweden: A deposit from an old phase of the Würm glaciation. Sveriges Geologiska Undersökning C 753. $62 \mathrm{p}$.

Bouchard, M.A., Gibbard, P. \& Salonen, V.-P. 1990. Lithostratotypes for Weichselian and pre-Weichselian sediments in southern and western Finland. Bulletin of the Geological Society of Finland 62, 79-95.

Donner, J. 1995. The Quaternary History of Scandinavia. Cambridge: Cambridge University Press. 200 p.

Donner, J., Korpela, K. \& Tynni, R. 1986. Veiksel-jääkauden alajaotus Suomessa (Summary: The subdivision of the Weichselian stage in Finland). Terra 98, 240-247.

Gibbard, P., Forman, S., Salomaa, R., Alhonen, P., Jungner, H., Peglar, S., Suksi, J. \& Vuorinen, A. 1989. Late Pleistocene stratigraphy at Harrinkangas, Kauhajoki, Western Finland. Annales Academiae Scientiarum Fennicae A III 150. 36 p.

Hirvas, H., Lintinen, P., Lunkka, J.P., Eriksson, B. \& Grönlund, T. 1995. Sedimentation and lithostratigraphy of the Vuosaari multiple till sequence in Helsinki, southern Finland. Bulletin of the Geological Society of Finland 67, 51-64.

Hirvas, H. \& Nenonen, K. 1987. The till stratigraphy of Finland. Geological Survey of Finland, Special Paper 3, 49-93.
Kurkinen, I., Niemelä, J. \& Tikkanen, J. 1989. Hienoainesmoreenia harjudeltan pohjalla. Summary: Fine-grained till underneath an esker delta. Geologi 41, 47-50.

Liivrand, E. 1991. Biostratigraphy of the Pleistocene deposits in Estonia and correlations in the Baltic region. University of Stockholm, Department of Quaternary Geology, Report 19. 114 p.

Lundqvist, J. 1986. Stratigraphy of the central area of the Scandinavian glaciation. Quaternary Science Reviews 5, 251-268.

Nenonen, K. 1992. Till stratigraphy in southern and western Finland. Bulletin of the Geological Society of Finland 64, 149-160.

Rainio, H. \& Lahermo, P. 1976. Observations on dark grey basal till in Finland. Bulletin of the Geological Society of Finland 48, 137-152.

Rainio, H. \& Lahermo, P. 1984. New aspects on the distribution and origin of the so-called dark till. Striae 20, 45-47.

Raukas, A. \& Kajak, K. 1997. Quaternary cover. In: Raukas, A. \& Teedumäe, A. (eds.) Geology and Mineral Resources of Estonia. Tallinn: Estonian Academy Publishers, 125-136.

Tynni, R. 1969. Geological Map of Finland 1:100 000. Maaperäkartan selitys, Riihimäki. Summary: Explanatory text to the map of Quaternary deposits. Sheet 2044, Geological Survey, Espoo. 95 p.

Ukkonen, P., Lunkka, J.P., Jungner, H. \& Donner, J. 1999. New radiocarbon dates from Finnish mammoths indicating large ice-free areas in Fennoscandia during the Middle Weichselian. Journal of Quaternary Science 14, 711-714.

Zilliacus, H. 1987. De Geer moraines in Finland and the annual moraine problem. Fennia 165, 145-239. 